\title{
The Influence of Price, Game Attractiveness, and Audience Preference on the Decision of Purchase Home Match Tickets Persib Bandung
} in Liga 1 Year 2019

\author{
Abdi Muhammad, Taufiq Marwa, Iyakrus Anas, Sulastri
}

\begin{abstract}
Football club in Indonesia income sources consist of four sectors, ranging from sponsorships, television broadcasting rights, sales of official club merchandise, and sales of match tickets. Match tickets are one source of income for a professional sports team. This study aims to determine the effect of price, game attractiveness, and audience preference on the decision to buy tickets for Persib Bandung home match in Liga 1 Year 2019. The data used in this study are primary data by distributing questionnaires to 400 peoples. The sample selection used in this study is a probability sampling method, with the Proposional Stratified Sampling technique. The sample will be divided into several categories based on the position of the stadium seating stands chosen by the respondents. The criteria for respondents determined by the researcher were ticket buyers for Persib Bandung home matches in Liga 1 Year 2019. The analysis technique used is multiple linear regression analysis. The results obtained from multiple linear regression analysis are price, game attractiveness, and audience preference simultaneously affect the decision to buy tickets for Persib Bandung home match in Liga 1 Year 2019. Price and audience preference variables partially influence the purchasing decision for Persib Bandung home match tickets in Liga 1 Year 2019. However, game attractiveness partially has no effect on the decision to purchase for Persib Bandung home match in Liga 1 Year 2019. This research is expected to be reference to choose which variable is better used in future studies. For organizing committee, this research can be a reference to increase sales of Persib match ticket sales in the following year's competition.
\end{abstract}

Keywords: Price, game attractiveness, audience preference, Purchase Decision, and Football Game Tickets.

\section{INTRODUCTION}

In accordance with Permendagri No. 22 year 2011, professional sports clubs cannot use Anggaran Pendapatan dan Belanja Daerah (APBD) for join competition. This makes professional sports clubs must be able to be

Revised Manuscript Received on September 13, 2020.

* Correspondence Author

Abdi Muhammad*, Master of Management, Sriwijaya University, Palembang, Indonesia. Email: abdee.weh@gmail.com

Taufiq Marwa, Faculty of Economics, Sriwijaya University, Palembang, Indonesia. Email: taufiqmarwa@yahoo.com

Iyakrus Anas, Department Physical and Sport Education at Sriwijaya University, Palembang, Indonesia. Email: iyakrusanas@gmail.com

Sulastri, Faculty of Economics, Sriwijaya University, Palembang,

(C) The Authors. Published by Blue Eyes Intelligence Engineering and Sciences Publication (BEIESP). This is an open access article under the CC BY-NC-ND license (http://creativecommons.org/licenses/by-nc-nd/4.0/) Indonesia. Email: sulastri2310@gmail.com

independent to meet their operational needs. Fajar Junaedi (2017) states that football club in Indonesia income sources consist of four sectors, ranging from sponsorships, television broadcasting rights, sales of official club merchandise, and sales of match tickets. Shobe (2008) states that a match ticket is a sports product that is born based on price. McFarland (2007) states that in a football stadium, ticket prices will be different for each side of the stadium. Each stand has different facilities. When tickets are sold out, the club can automatically earn revenue (Beccarini, 2006). Broocks (1994) states that ticket sales are always influenced by many things, from technical and non-technical aspects. Persib Bandung has decreased sales of match tickets in Liga 1 Year 2019 from the previous year's competition.

Table- 1. Comparison of sales of home match tickets

\begin{tabular}{ccc}
\hline Football Club & \multicolumn{2}{c}{ Liga 1 Year } \\
\cline { 2 - 3 } & $\mathbf{2 0 1 8}$ & $\mathbf{2 0 1 9}$ \\
\hline Persib Bandung & 272.291 & 256.200 \\
\hline
\end{tabular}

Source: Data from PT. Liga Indonesia Baru which is processed by researchers

Based on the table above, Persib experienced a decline in home match ticket selling by $5.9 \%$ from the competition in 2018. Some changes occurred when entering the competition in 2019. Persib moved to the Si Jalak Harupat Stadium, the policy of selling online ticket, and ticket price changes.

\section{LITERATURE REVIEW}

\section{A. Purchase Decision}

Kotler (2009: 240) states that purchasing decisions are consumer decisions regarding preferences for goods and services that exist among the many choices. According to Kotler (2009) there are six dimensions that can influence consumer decisions when making the purchase process, namely (1) Product selection decisions. Consumers can make decisions in purchasing goods or services for other purposes. In this case the company must be able to find a market that matches the goods or services that will be offered to consumers. (2) Decision of the brand chosen. Consumers must decide the brand of goods or services from one company, because each product has different characteristics and different. (3) Decisions regarding amounts. Consumers can make decisions to determine the amount of goods or services to be purchased. (4) Decisions on selected stores. There are several factors that are the reason a consumer chooses a store.

Published By:

Blue Eyes Intelligence Engineering

\& Sciences Publication

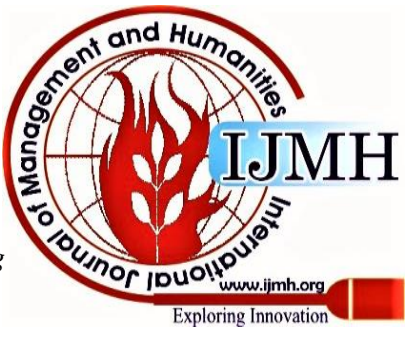


These factors can be in the form of price, suitable size, availability of complete items, convenience, and location. (5) Decisions regarding the time of purchase chosen.

Consumer decisions in making purchases can vary. (6) Decisions regarding payment methods.

B.Price

Kotler and Armstrong (2012) state that prices are the amount of value that must be paid to obtain the desired service. Kotler and Armstrong (2012) explain there are four dimensions found in prices, namely (1) Affordability of prices. Consumers are able to reach prices set by the company. Products usually consist of several types in one brand, but the price varies, ranging from the cheapest to most expensive. Many types of prices that are set will lure consumers to buy products. (2) Price according to ability or competitiveness. Consumers tend to compare prices of a product with other products. Expensive or cheap price of a product becomes a consideration of consumers when buying the product. (3) Price conformity with product quality. Price is often used as a benchmark of quality for consumers. Consumers tend to choose products with higher prices, due to quality differences. Higher prices tend to show better quality. (4) Price match with benefits. Consumers take the decision to buy a product whose benefits are greater or equal to the nominal money spent. When consumers feel the benefits of the product are less than the nominal amount of money spent, then consumers will start thinking about not making repeat purchases in the future.

\section{C.Game Attractiveness}

Hansen and Gauthier (1989) states that attractiveness games are the selling points of an interesting game to be observed and can influence the audience's desire to buy tickets and be present at the stadium. Game attractiveness consists of six dimensions, namely: (1) the track record of the previous game. The results of the match in the previous match were of concern for the audience to be present at the stadium. (2) team rankings in the league standings. The audience tends to be eager to buy match tickets when the team is in a good position. This has become a pride for the audience (3) star players. The actors on the gridiron become an interesting spectacle for the audience and the presence of star players will help improve team performance (4) the achievements and rankings of the opposing team. The quality of the opponent who will compete becomes a factor that determines the level of ticket sales. (5) rivalry between the two teams. The drama presented throughout the game and the history of past meetings are unique things that influence the decision to attend. (6) chances of winning. The home team won and celebrated together is a desire for every audience who buys tickets. The two teams that competed on the field were one of the keys to attract spectators to watch the match live at the stadium.

\section{Audience Preference}

Hansen and Gauthier (1989) mentioned that Audience Preference is a collection of behaviors from the habits of each individual to determine their presence at the stadium. This depends on the past experience and behavior of each individual. Audience Preference consists of six dimensions, namely (1) match schedule. Match schedule with daily activities becomes an important choice for consumers. (2) fan behavior during the game. The audience wanted to enjoy the match in an orderly manner and there were no riots at the stadium. (3) weather. Environmental conditions become a special consideration for the audience, in order to be able to enjoy the match. (4) Stadium selection. The distance between the residence and the stadium becomes a consideration for the audience. (5) transportation access to the match venue. Some spectators want to enjoy public transportation as an option to the stadium. (6) parking space availability. Spectators want their vehicles to be able to park in a comfortable place and not far from the stadium.

\section{CONCEPTUAL FRAMEWORK AND HYPOTHESIS}

To find out about the effect of price, game attractiveness, and audience preferences on the decision to purchase tickets for the Persib Bandung home match in Liga 1 Year 2019, the proposed research will be applied as follows:

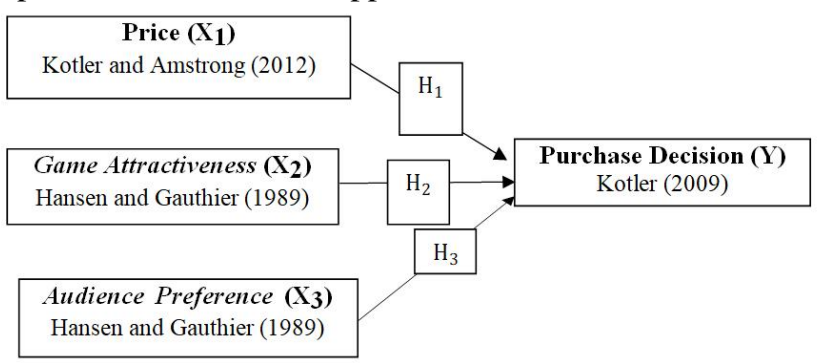

Source: Processed by researchers

Fig. 1. Conceptual Framework

The hypothesis is a temporary answer that is still conjectural and must still be verified, so with this hypothesis it is intended to provide an analytical direction from a study. Current provisions, namely:

1. H1: Price influences the decision to buy tickets for the home match of Persib Bandung in the Competition Liga 1 Year 2019.

2. H2: Game Attractiveness influences the decision to buy tickets for the home match of Persib Bandung in the Competition Liga 1 Year 2019.

3. H3: Audience Preference influences the decision to buy tickets for the home match of Persib Bandung in the Competition Liga 1 Year 2019.

\section{RESEARCH METHODS}

The scope of this research in the variables Price, Game Attractiveness, Audience Preference, and purchasing decisions. The object of this study was the audience who bought tickets for the Persib Bandung home match in the Competition Liga 1 2019. The population in this study were buyers of the Persib Bandung home match ticket in the Competition Liga 1 Year 2019, namely 256.200 people. The sample selection used in this study is the probability sampling method, with the Proposional Stratified Sampling technique. The sample will be divided into several categories based on the position of the stadium seating stands chosen by the respondents. Respondents criteria determined by the researcher are the buyers of the Persib Bandung home match tickets. To draw the number of samples the researcher used the Slovin formula, as follows:

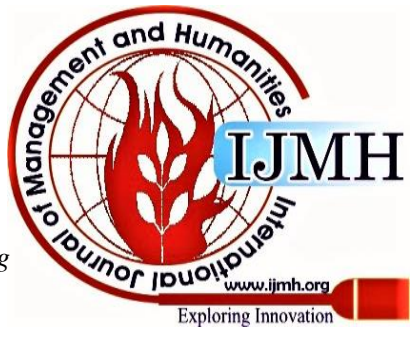




$$
\mathrm{n}=\frac{\mathrm{N}}{1+\mathrm{N}(\mathrm{E})^{2}}
$$

$$
\mathrm{n}=\frac{256.200}{1+256.200(0,05)^{2}}=399,376
$$

Information :

$\mathrm{N}$ : Population size

$\mathrm{E}$ : Standard error

$\mathrm{n}$ : number of samples

$$
\text { Source: Processed by researchers }
$$

Based on the results that have been tested with the Slovin formula, the number of samples obtained is 399,376 which if rounded to 400 . Samples in this study were 400 respondents, then it will be divided into six Audience Stand positions. Data collection techniques used in this study used a questionnaire.

\section{RESULTS AND DISCUSSION}

\section{A. Validity Test}

Table- 2. Price Variable Validity Test Results

\begin{tabular}{ccccc}
\hline No & Indicator & $r_{\text {hitung }}$ & r $_{\text {tabel }}$ & information \\
& & & & \\
\hline 1 & Price1 & 0,506 & 0,098 & Valid \\
2 & Price2 & 0,484 & 0,098 & Valid \\
3 & Price3 & 0,689 & 0,098 & Valid \\
4 & Price4 & 0,361 & 0,098 & Valid \\
5 & Price5 & 0,449 & 0,098 & Valid \\
\hline
\end{tabular}

Source: Questionnaire data processed using SPSS 26

Table 2 shows that the price variable has valid criteria for all items based on the criteria $r_{\text {hitung }}$ bigger than $r_{\text {tabel }}$.

Table- 3. Game Attractiveness Variable Validity Test Results

\begin{tabular}{ccccc}
\hline No & Indicator & $\mathrm{r}_{\text {hitung }}$ & $\mathrm{r}_{\text {tabel }}$ & $\begin{array}{c}\text { informatio } \\
\mathrm{n}\end{array}$ \\
\hline 1 & Game1 & ),659 & 0,098 & Valid \\
2 & Game2 & 0,675 & 0,098 & Valid \\
3 & Game3 & 0,158 & 0,098 & Valid \\
4 & Game4 & 0,671 & 0,098 & Valid \\
5 & Game5 & 0,680 & 0,098 & Valid \\
6 & Game6 & 0,495 & 0,098 & Valid \\
7 & Game7 & 0,728 & 0,098 & Valid \\
8 & Game8 & 0,676 & 0,098 & Valid \\
9 & Game9 & 0,331 & 0,098 & Valid \\
\hline \multicolumn{5}{l}{ Source: Questionnaire data processed using SPSS 26 }
\end{tabular}

Table 3 shows that the Game Attractiveness variable has valid criteria for all items based on the criteria $\mathrm{r}_{\text {hitung }}$ bigger than $\mathrm{r}_{\text {tabel. }}$.

Table- 4. Audience Preference Variable Validity Test Results

\begin{tabular}{ccccc}
\hline No & Indicator & rhitung & r tabel & information \\
\hline 1 & Audience1 & 0,415 & 0,098 & Valid \\
2 & Audience2 & 0,598 & 0,098 & Valid \\
3 & Audience3 & 0,322 & 0,098 & Valid
\end{tabular}

\section{Valid \\ Valid \\ Valid \\ Valid \\ Valid \\ Valid}

Source: Questionnaire data processed using SPSS 26

Table 4 shows that the Audience Preference variable has valid criteria for all items based on the criteria $r_{h i t u n g}$ bigger than $\mathrm{r}_{\text {tabel }}$.

Table- 5. Test Results of Variable Validity of Purchasing Decisions

\begin{tabular}{ccccc}
\hline No & Indicator & \multicolumn{1}{c}{$\mathrm{r}_{\text {hitung }}$} & $\mathrm{r}_{\text {tabel }}$ & information \\
\hline 1 & PD1 & 0,576 & 0,098 & Valid \\
2 & PD2 & 0,521 & 0,098 & Valid \\
3 & PD3 & 0,548 & 0,098 & Valid \\
4 & PD4 & 0,539 & 0,098 & Valid \\
5 & PD5 & 0,464 & 0,098 & Valid \\
6 & PD6 & 0,537 & 0,098 & Valid \\
\hline
\end{tabular}

Table 5 shows that the Purchasing Decisions variable has valid criteria for all items based on the criteria $\mathrm{r}_{\text {hitung }}$ bigger than $r_{\text {tabel. }}$ Based on table 2 to table 5 shows valid results. All items that describe the indicators of the four research variables are valid, because all $r$ hitung $>r$ tabel are 0.098 . The validity of all statement items means that the measuring instrument used in this study is able to measure the object to be measured.

\section{B. T Reliability Test}

The reliability test in this study uses SPPS 26 software, which provides a facility to measure reliability with the Croncbach Alpha statistical test. A variable is said to be reliable if it gives a Croncbach alpha value $>0.600$. The reliability test results are presented in the following table.

Table- 6. Reliability Test Results

\begin{tabular}{llll}
\hline Variables & $\begin{array}{l}\text { Cronbach's } \\
\text { Alpha }\end{array}$ & $\begin{array}{l}\text { Reliabel } \\
\text { Scores }\end{array}$ & information \\
\hline Price (X1) & 0,610 & 0,600 & Reliabel \\
\hline $\begin{array}{l}\text { Game } \\
\text { Attractiveness } \\
\text { (X2) }\end{array}$ & 0,810 & 0,600 & Reliabel \\
\hline
\end{tabular}

\begin{tabular}{llll}
\hline $\begin{array}{l}\text { Audience } \\
\text { Preference } \\
\text { (X3) }\end{array}$ & 0,741 & 0,600 & Reliabel \\
\hline $\begin{array}{l}\text { Purchasing } \\
\text { Decisions (Y) }\end{array}$ & 0,708 & 0,600 & Reliabel \\
\hline
\end{tabular}
Source: Questionnaire data processed using SPSS 26

$$
\begin{aligned}
& \text { \& Sciences Publication } \\
& \text { (C) Copyright: All rights reserved. }
\end{aligned}
$$


Based on Table 6 it can be concluded that the cronbrach's alpha value is above 0.600 . This shows that the Price, Game Attractiveness, Audience Preference, and purchasing decision variables all show numbers greater than 0.600 , which means that the measurement tools for both variables in this study are all declared reliable.

\section{Normality Test}

Normality test is performed to determine whether the data taken in the study come from populations that are normally distributed or not normal. A good regression model is data that is normally distributed or close to normal. If the data is not around the diagonal line region and does not follow the diagonal line or does not follow the normal distribution pattern, then a biased estimate will be obtained. Testing the normality in this study through the normal probability plot using SPSS 26 and obtain the following results:

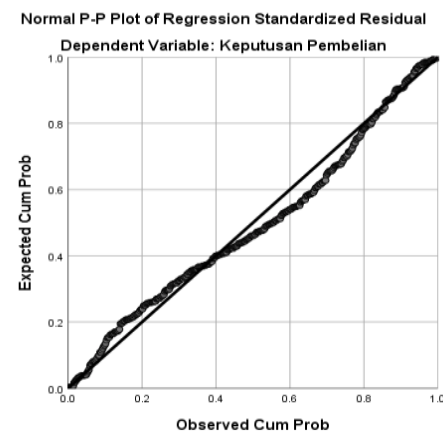

Fig. 2. Normality Test Results

Source: Questionnaire data processed using SPSS 26

The normality test with the normal probability plot requires that the data spread be around the diagonal line region and follow the direction of the diagonal line. Based on the picture above, it can be concluded that the data in this study meet the normal probability plot requirements so that the research meets the normality assumptions, which means that the data in this study come from normally distributed populations.

\section{Multicollinearity Test}

Multicollinearity test is performed to determine whether there is a correlation between independent variables, namely by calculating the value of Variance Inflation Factor (VIF). Data that does not contain multicollinearity is data that has a VIF value of less than 10 . The multicollinearity calculation results are statistically as follows:

\begin{tabular}{lcc} 
Table- 7. Multicollinearity Test Results \\
\hline Model & \multicolumn{2}{c}{$\begin{array}{c}\text { Collinearity } \\
\text { Statistic }\end{array}$} \\
\cline { 2 - 3 } & Tolerance & VIF \\
\hline (constant) & & \\
Price (X1) & 0,806 & 1,240 \\
Game & & \\
Attractiveness & & \\
(X2) & &
\end{tabular}

Audience $\quad 0,736 \quad 1,358$

Preference

(X3)

$$
0,794 \quad 1,259
$$

Source: Questionnaire data processed using SPSS 26

Based on Table 7 , the multicollinearity test results above can be seen that the VIF value for the variable price, Game

Attractiveness, and Audience Preference is less than 10. This shows that there is no multicollinearity between the independent variables. Tolerance value for the variable price, Game Attractiveness, and Audience Preference is more than 0.1 . This shows that there is no multicollinearity between independent variables.

\section{DATA ANALYSIS AND HYPOTHESIS TEST}

This study consists of four variables consisting of price, game attractiveness, and audience preference as independent variables and purchasing decisions as the dependent variable.

\section{A. Multiple Regression Analysis}

Multiple linear regression analysis is used to determine the magnitude of the effect of price, Game Attractiveness, and Audience Preference partially or simultaneously on purchasing decisions. Statistical calculations in multiple linear regression analysis can be seen in the following table:

Table- 8. Multiple Regression Analysis Results

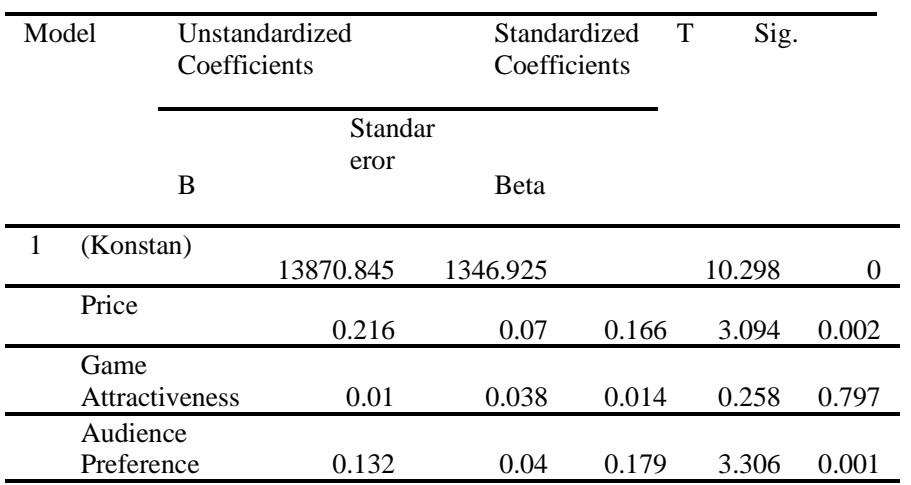

a. Dependent Variable: Purchasing Decisions

Source: Questionnaire data processed using SPSS 26

\section{Regression Model:}

\section{Purchasing Decision $=$ \\ $a+b_{1}$ Price $+b_{2}$ Game $+b_{3}$ Audience $+e$}

Purchasing Decisions =

$$
13870.845+0.216 \mathrm{X}_{1}+0.010 \mathrm{X}_{2}+0.132 \mathrm{X}_{3}
$$

From this equation, it can be explained that:

1. The constant (a) is 13870,845 , the regression equation above means that if all variables are omitted or in mathematical calculations $=0$, then the purchase decision that occurs at that time is 13870,845 .

2. The $\mathrm{X} 1$ coefficient of 0.216 is positive, so mathematically, if there is a change of $1 \%$ in the independent variable $\mathrm{X} 1$, it will result in changes in the dependent variable in the same direction of 0.216 if the other variables are constant.

3. The coefficient of X2 0.010 is positive, so mathematically if there is a change of $1 \%$ in the independent variable $\mathrm{X} 2$ it will result in changes in the dependent variable in the same direction of 0.010 if the other variables are constant.

4. The X3 coefficient of 0.132 is positive, so mathematically if there is a change of $1 \%$ in the independent variable X3 it will result in changes in the dependent variable in the same direction of 0.132 if the other variables are constant.

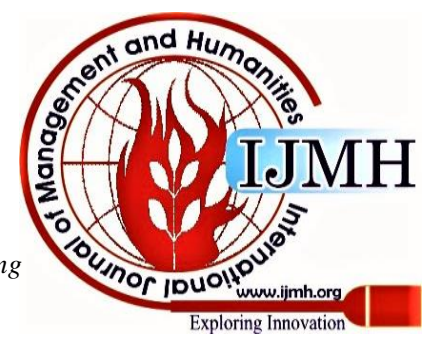




\section{B. Test Results F}

The $F$ test is used to determine the effect of the independent variable price, Game Attractiveness, and Audience Preference simultaneously on the dependent the simultaneous or joint testing of variables.

Table- 9. Test Results F

\begin{tabular}{|c|c|c|c|c|c|}
\hline \multicolumn{6}{|c|}{ Anova $^{a}$} \\
\hline Model & $\begin{array}{l}\text { Sum of } \\
\text { Squares }\end{array}$ & df & $\begin{array}{r}\text { Mean } \\
\text { Square }\end{array}$ & $\mathrm{F}$ & Sig \\
\hline $\begin{array}{c}1 \\
\text { Regression }\end{array}$ & 291864913 & 3 & 97288304 & 11.9 & $.000^{\mathrm{b}}$ \\
\hline
\end{tabular}

\begin{tabular}{cccc}
\cline { 2 - 4 } Residual & $3.238 \mathrm{E}+09$ & 396 & 8175626.4 \\
Total & $3.529 \mathrm{E}+09$ & 399
\end{tabular}

\begin{tabular}{l} 
a. Dependent Variable: Purchasing Decisions \\
\hline b. Predictors: (Constant), Audience Preference, Price, Game \\
Attractiveness
\end{tabular}

Attractiveness

Source: Questionnaire data processed using SPSS 26

\section{Test Results $t$}

Test result $t$ is used to determine the effect of partially independent variables price, Game Attractiveness, and Audience Preference on the dependent variable purchase decision. The following will explain the partial testing of each variable. The result of $t$ table calculation is 5\%: $2=$ $2.5 \%$, df $(n-1,400-1=399)$. The results obtained for t table is 1,962 . The significance used is less than 0.05 , so based on the results of the partial test ( $t$ test) in the table above, for the three price-independent variables, Game Attractiveness, and Audience Preference are explained as follows:

a. Effect of Price (X1) on Purchasing Decisions (Y)

Price (X1) shows that the significance for $\mathrm{X} 1$ to $\mathrm{Y}$ is $0.002<\alpha=0.05$ and $\mathrm{t}_{\text {hitung }} 3.094>\mathrm{t}$ tabel 1.962. So it can be concluded that $\mathrm{H}_{1}$ is accepted. This means that the price (X1) has a positive and significant effect on the decision to purchase Persib home game tickets in the Liga 12019. Changes in ticket prices must certainly be a consideration for organizing committee in determining pricing policies in the following year's competition.

\section{b. Effect of Game Attractiveness (X2) on Purchasing \\ Decisions (Y)}

Game Attractiveness (X2) shows that the significance for $\mathrm{X} 2$ against $\mathrm{Y}$ is $0.797>\alpha=0,05$ dan $\mathrm{t}$ hitung $0,258<\mathrm{t}$ tabel 1,962. Then it can be concluded that $\mathrm{H}_{2}$ is rejected. This means that Game Attractiveness (X2) does not significantly affect the decision to purchase Persib home game tickets in the Liga 1 2019. The audience does not care about the results of the match obtained by the team that is proud of. They still support their proud team, even though the team lost at home. c. Effect of Audience Preference (X2) on Purchasing

\section{Decisions ( $\mathbf{Y}$ )}

Audience Preference (X3) shows that the significance for $\mathrm{X} 3$ against $\mathrm{Y}$ is $0.001<\alpha=0.05$ and $\mathrm{t}$ hitung 3,306 $>\mathrm{t}$ tabel 1,962. Then it can be concluded that H3 is accepted. This means that Audience Preference (X3) has a positive and significant effect on the decision to purchase Persib home game tickets in the Liga 1 2019. Changing the stadium variable on purchasing decisions. The following will explain

becomes a matter that affects the desire to buy tickets and be present at the stadium.

\section{D.Correlation Coefficient (R) and Coefficient of Determination $\left(\mathbf{R}^{2}\right)$}

The correlation coefficient $(\mathrm{R})$ aims to determine the closeness of the relationship between the influence of independent variables on the dependent variable. Meanwhile, the coefficient of determination is used to find out how much influence the interaction variable. The results of data processing using SPSS are as follows:

Table- 10. Test Correlation Coefficient (R) and Coefficient of Determination $\left(\mathbf{R}^{\mathbf{2}}\right)$

\begin{tabular}{|c|c|c|c|c|}
\hline \multicolumn{5}{|c|}{ Model Summary } \\
\hline Model & $\mathrm{R}$ & R Square & $\begin{array}{l}\text { Adjusted } \\
\text { R Square }\end{array}$ & $\begin{array}{l}\text { Std. } \\
\text { Error of } \\
\text { the }\end{array}$ \\
\hline 1 & $.288^{\mathrm{a}}$ & 0.083 & 0.076 & 2,859.31 \\
\hline
\end{tabular}

Correlation coefficient of 0.288 which indicates that the relationship between price, Game Attractiveness, and Audience Preference as independent variables on purchasing decisions as the dependent variable is at the level of a weak relationship. Meanwhile, the coefficient of determination ( $R$ square) obtained a figure of 0.083 . This means that the variable price, Game Attractiveness, and Audience Preference have the effect of contributing $8.3 \%$ to the decision to buy Persib home game tickets in the Liga 12019 and the other $91.7 \%$ is influenced by other variables not examined in this research.

\section{CONCLUSIONS}

This study is intended to determine the effect of price, Game Attractiveness, and Audience Preference on the decision to purchase tickets for Persib Bandung home matches in Liga 1 2019. Based on the description of the research results and discussion, the conclusions of this study can be drawn:

1. Simultaneously the price variable, Game Attractiveness, and Audience Preference affect the purchasing decision Persib Bandung home match tickets in Liga 12019.

2. Partially, the price variable influences the decision to buy Persib Bandung home match tickets in Liga 12019.

3. Partially the game attractiveness variable has no effect on the purchasing decision Persib Bandung home match tickets in Liga 12019.

4. Partially the audience preference variable has an effect on the purchasing decision Persib Bandung home match tickets in Liga 12019.

Based on the results of the analysis and discussion in this study, the suggestions that can be given are:

1. For organizing committee

Organizing committeeis expected to be able to consider several policies related to the Persib home match, ranging from prices, stadium selection, etc.

Published By:

Blue Eyes Intelligence Engineering

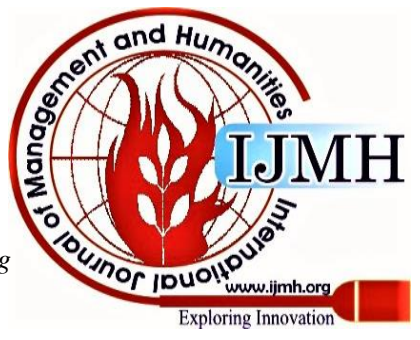




\section{For further researchers}

There is still much that can be worked on from research into football matches, ranging from promotions, service quality, etc. Hopefully more and more are open to doing research about football matches.

\section{REFERENCES}

1. Beccarini, C. 2006. Factors affecting soccer club ticket holders'satisfaction: The influence of clun image and fan's motives. European Sport Management Quarterly. 6 (1): 1 - 22.

2. Borland, J. 2003. Demand for sport. Oxford Review of Economic Policy, 19(4), 478-502.

3. Brooks, C.M. 1994. Sports marketing: Competitive business strategies for sports. Englewood Cliffs, NJ: Prentice Hall.

4. Hansen, H., \& Gauthier, R. 1989. Factors affecting attendance at professional sport events. Journal of Sport Management, 15-32

5. Junaedi, Fajar. 2017. Merayakan Sepakbola: Fans, Identitas, dan Media Edisi I. Sleman: Fandom.

6. Junaedi, Fajar. 2017. Merayakan Sepakbola: Fans, Identitas, dan Media Edisi II. Sleman: Fandom.

7. Kotler, Amstrong. 2012. Manajemen Pemasaran. Jakarta: Penerbit Erlangga.

8. Kotler, Philip. 2009. Manajemen Pemasaran. Jakarta: Penerbit Erlangga.

9. LIB. Annual Report Liga 1 tahun 2018. 2019. Jakarta: PT Liga Indonesia Baru.

10. LIB. Annual Report Liga 1 tahun 2019. 2020. Jakarta: PT Liga Indonesia Baru.

11. McFarland, A. 2007. Building a mass activity: Fandom, class and business in early Spanish football. Soccer \& Society, 8 (2-3) 205-220.

12. Peraturan Menteri Dalam Negeri, Nomor 2 Tahun 2017, tentang Penggunaan Dana APBD.

13. Schaaf, P. 1995. Sports Marketing: It's not a Game Anymore. Promethus Books.

14. Shobe, H. 2008. Place, identity and football: Catalonia, Catalanisme and Football Club Barcelona, 1899-1975. National Identities, 10 (3), 329-343.

15. Siregar, Syofian. 2013. Metode Penelitian Kuantitatif. Jakarta: PT Fajar Mandiri.

16. Sugiyono. 2017. Metode Penelitian Kuantitatif dan Kualitatif. Bandung: Alfabeta.

\section{AUTHORS PROFILE}

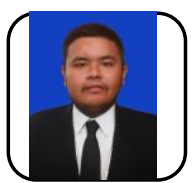

Abdi Muhammad, he recently received a master's degree from Sriwijaya University, Palembang, Indonesia. He obtained a bachelor's degree from Padjadjaran University, Bandung, Indonesia, with a Bachelor of Humanities degree. A researcher on sports event management.

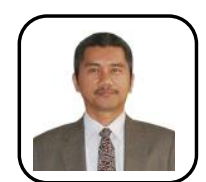

Taufiq Marwa, he is a professor at the Faculty of Economics, Sriwijaya University, Palembang, Indonesia. He works as a lecturer in the Faculty of Economics, Sriwijaya University, Palembang, Indonesia.

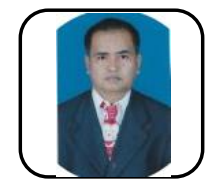

Iyakrus Anas, he is a doctor at department Physical and Sport Education at Sriwijaya University, Palembang, Indonesia. He works as a lecturer in department Physical and Sport Education, Sriwijaya University, Palembang, Indonesia.

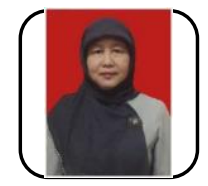

Sulastri, she is a professor at the Faculty of Economics, Sriwijaya University, Palembang, Indonesia. She works as a lecturer in the Faculty of Economics, Sriwijaya University, Palembang, Indonesia.

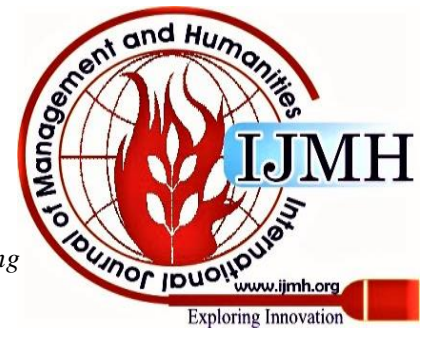

